\title{
TRADITION AND PROGRESS, FUTURE AND PAST IN THE NOVELS OF MARIA MESSINA
}

\section{LARA GOCHIN RAFFAELLI}

\begin{abstract}
Sommario
Maria Messina scrisse i suoi romanzi tra il 1920 e il 1928, quando il fascismo aveva troncato l'emancipazione femminile e rinforzato le strutture patriarcali. I suoi personaggi femminili rispecchiano $i$ conflitti dell'epoca, divisi tra $i$ richiami contrastanti della tradizione e del progresso, di passato e futuro. Nei primi romanzi le donne sono sottomesse, accettano e perpetuano l'autorità maschile. Negli ultimi romanzi, invece, sono più forti e decise nella ricerca dell'autonomia. La difficoltà di opporsi alle norme socio-culturali si manifesta nel frequente ritorno alla convenzione o nell'obliterazione di sé. Questo ritratto dell'abbietta condizione femminile è un'accusa implicita ma forte della società dell'epoca.
\end{abstract}

Maria Messina wrote her six novels between 1920 and 1928, a period of great tension and flux which saw the rise of Fascism and its invasion of every aspect of Italian life. The nascent women's emancipation movement had been halted in its tracks by the Fascist regime, which reinforced male supremacy and confined women to the domestic realm.

Regarding Grazia Deledda's La madre, Spinazzola (1987:11) wrote that

Alla base dei suoi libri c'è sempre un urto fra vecchio e nuovo: l'impulso a contravvenire alla legge deriva da un 
mutamento di stato sociale o di condizione morale, comunque da un arricchimento di esperienza che induce il protagonista a guardare con occhi diversi il mondo di cui ha sinora condiviso l'ordine.

Messina, whose novels were published at the same time as Deledda's later works, is witness to the same changing age. Her characters are fraught with ambivalence and conflict, mirroring that "urto fra vecchio e nuovo" seen in Deledda, and exemplifying not only the changing times but also the difficulty in confronting change and effecting it. According to Elisabetta Rasy, this ambivalence is typical of the woman writer's situation in Messina's epoch: "La scrittrice del nuovo secolo sta dunque a mezza via fra la rabbia e il rimpianto: la rabbia che spinge all'emancipazione, all'eguaglianza con gli uomini; il rimpianto per il femminile, traccia arcaica e differenza profonda, che viene sacrificato nel cercare l'emancipazione imitando l'uomo" (1984:76-77).

The most emblematic of women writers striving for independence and progress is considered to be Sibilla Aleramo, whose novel, Una donna, published in 1906, offered "a significant new understanding of womanhood and women's right to emancipation", and is "assumed to be the starting-point of feminist writing" in Italy (Quartermaine, 1991:232). Quartermaine describes in Aleramo the "profound generation gap between mother and daughter. While the former was submissive according to traditional rules, the latter grew more and more intolerant of those rules; and their opposition to one another called into question the whole structure of social structures, of patriarchal authority, and of cultural models" (233). This generational gap in attitudes towards tradition and progress, past and future, felt so strongly by Aleramo, is reflected also in Messina's characters. Those representing past and tradition are found in Messina's early works, while in later novels characters display desire for 
liberation and independence. Some novels portray characters symbolising tradition and others the striving for emancipation; some show the mother/daughter or aunt/niece generation gap described by Quartermaine; significantly one may see in the character initially symbolising future and progress, a subsequent retrogression to tradition and convention.

A movement which has rarely been associated with Messina's writing, but which may be seen to influence aspects of her work, especially her female characters' attitudes towards progress and the future, is that of Futurism, established by Filippo Tommaso Marinetti in 1909 (Gherarducci, 1976:27n), and still an active movement at the time of her writing. Many of Messina's characters appear to embrace the ideals Marinetti extolled, which glorified the future, speed, and rejection of tradition. Messina's seeming interest in the movement's principles, which tended to be highly critical of women, could be considered paradoxical for a woman writer who accentuates the miserable condition of women. At the time of writing of Messina's major works, not only was Futurism still holding strong, but it also influenced the Fascist regime and its ideals of violence, war, aggression, and of man as soldier (Wood, 1995:xiii). Futurism's "misogynous attitude [....] as expressed in Marinetti's manifesto Contro l'amore e il parlamentarismo" assisted Fascism in "returning women to the home" and inspired "Mussolini's dictum that "maternity is to women what war is to men"" (Quartermaine, 1991:235). Futurist ideas on women were profoundly contradictory. In its quest for liberation from the past and from past modes of behaviour and expression, the Futurists promoted equality for women - "Abolizione dell'autorizzazione maritale. Divorzio facile. Svalutazione graduale del matrimonio per l'avvento graduale del libero amore" (Marinetti, 1990:154). However, Wood observes that while Futurism "opened up new debates on social organization and gender role", it "failed to produce a body of work that would detach women from their conventional roles" 
(1995:xiii). As Wood further notes, "Their affirmed belief in free love seemed to be something of a one-way process, and the role of reproducer rather than producer, the Maker of Heroes, assigned to women in the new Futurist society was almost indistinguishable from that proposed by Fascism" (1995:100). The Futurism movement was "linked to a profound contempt for women and for feminism in particular" (105). It viewed women in that age-old dichotomy of man/culture and women/nature: "Woman, slave to sentimental passions and to the family, was identified with the natural world, symbol of the earth to be abandoned, while Futurism embraced technology and the machine, speed and flight" (105). Despite these paradoxes, perhaps Futurism, misogynistic as it was, held for Messina the promise of independence and liberty for all women and the removal of the "subjectivity", "passivity and immobility" (Nicholls, 1989:204) associated with their role. Nicholls observes that "Marinetti saw past cultures (and Italian culture in particular) as locked into social and psychological roles which were deeply repressive [...]"; what Marinetti aimed to abolish were "the entailments not merely of traditional femininity but of sexual difference itself" (203). As Messina's novels progress chronologically, her female characters increasingly reject the imposition of the traditional feminine role and the constraints that this sexual difference inflicts on them in terms of career choice and lifestyle. The conflict and ambiguity inherent in Marinetti's view of femininity is not unique to Marinetti or to Futurism; one could argue that it represents the dichotomous view of women as angels/devils since time and literature began (think of the Bible's Eve/Lilith); Marinetti's view of women as "objects of poetic contemplation and romantic idealism, but as objects of loathing as well" (Orban, 1995:53) is one that has persisted through the ages. Replicating this ambivalence in the view of women by society is the ambivalence felt by women themselves towards their role and position in society. Some of the foremost women writers of the age, amongst others 
Matilde Serao and Neera (Wood, 1995:46), showed great ambivalence in this regard, especially with regard to women writing or to the idea of feminism itself. Gina Lombroso, who worked to uplift the situation of women, promoted the "angel of the hearth" image of women, encouraging women to leave the workplace to which they had acceded and return to the home where they belonged, in her books L'anima della donna (1921) and La donna nella vita (1923). In Messina's works, this ambivalence filters through in her story-lines and characterisations; they reflect the conflicting messages being received from all sides in Italian life at this time, whether from movements such as Futurism, the women's movement, women writers and society itself.

In Messina's novels, women's perceptions of their roles, duties and possibilities in life change. We will see through examples taken from her various novels that her characters do not always succeed in fulfilling their dreams of self-realisation - in fact they rarely do - but from our twentyfirst century perspective, it is of historical, cultural and social importance to see how an author living in 1920s Italy struggled with the conflicts and huge challenges of the age, to represent the battle for female selfdetermination. Messina is cognisant of the difficulty in opposing norms long embedded in the communal psyche. Her novels show her female characters' reluctance to defy convention, often returning to the status quo or worse. Her early female characters, submissive and accepting of their fate, demonstrate how women have absorbed male authority to the extent that they perpetuate it and transmit it to other women, which Bimbi describes as "la figura materna come prevalente agente di trasmissione dell'autoritarismo paterno da essa interiorizzato" (1977:24). Italian culture in Messina's epoch was rigidly patriarchal and had been so for millennia. The Roman Catholic Church was a powerful central force in Italian life, described by Evans as the "most persistent and intractable of the feminists' enemies" (1977:124). Catholic doctrine emphatically stressed 
women's inferiority to men: "In catholic doctrine, as in secular law, woman's role was subordination to her husband; her circle of activity was the family" (Chiavola Birnbaum, 1986:15). This forced subjection of women to the authority of men had a long religious and legal history, its enforcement by religious leaders in Italy dating back almost two thousand years, to Augustine's era (354-430 AD): "The relationship between men and women is hierarchical; Augustine stated that women should consider their husbands masters" (35). Reinforcing this patriarchal authority, in the early 1800s the Napoleonic code was established, which, becoming "the model for most European legislation fixed a condition of inferiority for women and a double standard of sexuality for men and women. Women were under the guardianship of men - first fathers, then husbands" (13). The subordination of women "was reaffirmed by Pius X in 1909" (35). By the end of the 1920s, with the Fascist regime fully in control of Italian life, women's subordination was once again reinforced with the introduction of various laws "hostile to women" (39). Ferdinando Loffredo affirmed in 1938 that the woman "deve tornare sotto la sudditanza assoluta dell'uomo: padre o marito; sudditanza, e quindi inferiorità: spirituale, culturale ed economica" (Loffredo, 1938:369). In 1942 , the law of pater potestas, reaffirming male authority, was passed (Quartermaine, 1991:235).

In the face of legal, cultural, religious and social subordination of women to male authority, Messina's reluctance to show greater recalcitrance in her characters towards their situation is easily understood. Nonetheless, her objection to their subordination is clear, developing in linear form through her novels. There appears to be in Messina's early novels (Primavera senza sole (1920), Alla deriva (1920) and La casa nel vicolo (1921)) a channelling of the frustrated aspirations of women through her male protagonists, in what Elaine Showalter describes as dealing with "personal ambition by projecting the ideology of success 
onto male characters, whose initiative, thrift, industry and perseverance came straight from the woman author's experience" and who were "often a more effective outlet for the 'deviant' aspects of the author's personality than were her heroines" (1977:28). Messina appears to weave her own literary desires into the fabric of her stories: productivity is represented by writing, while achievement is shown as literary success. Imbuing her male characters - untrammelled by societal restrictions and free to pursue any occupation - with these aspirations, could be Messina's way of providing a mouthpiece for her female characters' ambitions.

We should pause here to consider the meaning of "ambitions" for women. Work for women was not prohibited in Italy - far from it: statistics show that women had worked for centuries alongside men in the fields and later in factories, in huge numbers - "The 1881 Census found that 5.7 million out of 11 million women aged 10 or over were 'active"" (Wood, 1995:5) - and significantly, under exploitative and punishing conditions: the working day could be as long as 16 hours, and women by law earned one-half of what men earned (6). Work as a career, rather than labour, providing self-fulfillment and social status, was not something to which women were permitted to aspire: this was reserved for men, for whom "work satisfied both self-interest and the public interest. In pursuing their ambitions, they fulfilled social ambitions. For women, however, work meant labor for others" (Showalter, 1977:22). In Italy (and elsewhere), only certain careers were available for women. Teaching, journalism and writing were some of the only professional options available to women: "[A]lle donne erano preclusi quasi tutti i pubblici impieghi e scarse erano le possibilità di essere assunte in uffici privati. L'insegnamento finiva così per offrire alle donne comunque una chance, una possibilità di occupazione" (Turnaturi, 1993:102). However, teaching, was not an altogether desirable professional option: "Altissimo fu infatti per il primo decennio del Novecento il numero di suicidi fra le maestre 
che, stremate dalle maldicenze, dai ricatti e da una vita grama finivano per scegliere il fiume o le rotaie della ferrovia" (102). In Messina's novels, her women characters increasingly strive to find work that promotes fulfillment and self-realisation, and teaching is gradually seen to be something that does not permit this.

Characters in Messina's first three novels generally accept patriarchal hegemony. Nicolina, the protagonist of La casa nel vicolo, expresses sentiments like "Non ti affliggere. Papà ha ragione" (to little Alessio, whose Papà has just forbidden him to read "romanzacci" by Foscolo); and she reflects on her brother-in-law, don Lucio, the origin of the affliction: "Come Alessio poteva ribellarglisi dentro il cuore? Egli [don Lucio] era un uomo che non si sbagliava mai, che conosceva il bene e il male. Bisognava affidarsi a lui come al marinaio che guida la barca in alto mare. È così bello aver fiducia in qualcuno [...]" (Messina, 1992:57). In Alla deriva the following observation is made: "Non si deve disubbidire alle leggi semplici e naturali che regolano l'esistenza della nostra gente" (Messina, 1920b:153-4). Counter-current to the conviction that the status quo is correct and just, simple and natural, is the awakening of women's knowledge that they do not have to accept their entrapment and state of submission. In Messina's novels, awareness arises that the oppressed state exists only because the oppressed parties have allowed it, and that alternative life choices may be made. Symbolising this new awareness are Messina's characters who rebel against convention. Initially, these characters are marginal to the central story-line, but act as catalysts in the awakening of consciousness.

The notion of work as self-realisation is developed gradually throughout the novels. In Messina's first novel, Primavera senza sole, the protagonist Orsola is studying to become a teacher to support her impoverished family. While powerful maternal sentiment ultimately provides the most satisfaction in Orsola's life, the concept of intellectual 
autonomy is touched upon briefly. Orsola wants to fulfil a need within herself: "Ella aveva bisogno di "fare qualcosa di utile" (Messina, 1920a:88). However, her work remains in the context of maternal caregiver, with children - women's traditional and prescribed role: "Amava i bimbi [...] E spiegava la lezione con l'anima invasa da una sconfinata tenerezza, con una ineffabile voglia di stringere in un solo abbraccio tutte quelle creature che la guardavano con gli occhi attenti e le fresche boccucce socchiuse" (88). Orsola's need for personal expression is translated into strong maternal feeling: her identity is fused with the role of the mother and she finds realisation in this identity. However, when Orsola meets Donatella, the studious daughter of a judge, Orsola ponders:

Possibile che quella leggiadra creatura non pensasse che ai suoi libracci e non desiderasse altro che laurearsi e vedere le pietre di Taormina? [...] Pure, in quel momento, sentì una specie di vergogna del proprio bisogno di amare e di essere amata. Ammutolì, non sapendo come continuare. Con quella giovanetta non si poteva chiacchierare delle solite cose comuni, che formavano l'argomento della conversazione di Sara e delle compagne di scuola. (78-9)

While this encounter does not change Orsola's career path, it opens her eyes to the concept of female intellectual development: "una volta a casa, rimpianse 'quella' compagna. Sentì di avere respirato, per un momento, un'aria più libera e più netta dell'aria che l'aveva circondata finora" (79).

In Alla deriva, the expression of female intellect is rapidly quashed. Simonetta, the protagonist, is the daughter of the revered Professor Montebello, and is intellectual and eloquent: “ - Solo - aggiunse Simonetta, con improvvisa serietà - è troppo demolitore. Distruggere senza edificare è una cosa scoraggiante" (Messina, 1920b:5-6). This quote 
recalls one made by Lelia in Fogazzaro's Leila: "Ella ricorderà forse la mia antipatia per le novità religiose, per le idee che mi parevano buone a distruggere e non a edificare" (Fogazzaro, 1968:933), and could be seen to exhibit Simonetta's literary education. The novel continues by illustrating her depth of culture: "Durante il tè si parlò di teatro e di pittura. E Simonetta raccontò un aneddoto che il padre non conosceva" (Messina, 1920b:5-6). However, Simonetta's intellectual development goes no further, as she marries Marcello Scalia, one of her father's students. In the ensuing boredom which characterises Simonetta's life as a married woman, she makes an effort at self-determination: "Io te l'ò proposto mille volte - replicò Simonetta - Ti aiuterei così volentieri! Non dico che tu abbi bisogno dei miei lumi! Ma guidata, potrei fare per te delle ricerche in Biblioteca, dei riassunti... Così, vedi ... - confessò timidamente - le mie giornate sarebbero riempite di qualche cosa." This request is denied, and her husband answers: "Non ti basto più?" (71). Deprived of purpose and cerebral stimulation, Simonetta turns to a trivial outlet for her need for productivity, namely self-embellishment: "Simonetta fu lieta di aver trovato uno svago che le riempisse le giornate mentre il marito lavorava. [...] Le faceva piacere praticare una signora del paese, per avere una specie di rivincita sulle meschine ambizioni delle mogli dei colleghi” (77).

Elaine Showalter describes Lily Bart's circumstances in Edith Wharton's The House of Mirth: "In her powerful analysis of Lily Bart's disintegration, Wharton 'could turn her fury upon a world which had enjoined women to spend their artistic inclinations entirely upon a display of self. Not the woman as productive artist but the woman as self-creating artistic object [...]"”. Wharton's novel is described as "both a critique of the artistic representation of women - the transformation of women into beautiful objects of male aesthetic appreciation - and a satiric analysis of the artistic traditions that 'had evolved no conventions designed to render a woman as the maker of beauty, no language of feminine growth and 
mastery"' (Showalter, 1991:88, citing Griffin Wolff, 1977:11). The same can be said of Alla deriva. If each of Messina's novels represents a stage in the process towards women's emancipation, Simonetta could be seen as the woman aware of her potential but unable to fight against society's rigidly enforced roles and her husband's traditional view of her wifely duties. She is also beset by conflicting attitudes regarding the roles of men and women: "Si, pensò, noi non desideriamo altro che essere guidate e sorrette, nelle vie della vita, da un uomo forte e onesto" (Messina, 1920b:59). " - Non vorrei nulla - ripetè Simonetta convinta -. A me piace una cosa solo perchè piace a te" (63). These pronouncements indicate a fundamental belief in her own weakness and a subordination of her own personality to Marcello's.

Marcello Scalia presents an ambiguous figure. He is dominating and he manages to quell the light that would have been his wife. His literary efforts go nowhere, barring one success which comes too late to save his credibility and self-pride. Marcello's only strength is his unrelenting pride, and he constantly lies to Simonetta about the progress of his work. There is an inversion of roles and capabilities in the novel, which casts a sardonic light on the traditional gender order and tacitly condemns it: the male, free to explore his intellectual and creative potential, is unequal to the task, whereas the female, who shows promise and intelligence, but to whom such freedom is denied, is constrained to fritter her life away in frivolous activity.

In this novel, an allusion to flight is made. Whereas this could simply be a reference to the novelties of the age, it could also be a reference to Futurism, which glorified the concepts of technology, power and speed. Simonetta's mention of flying could be a symbol of her desire for freedom: "l'aviazione è di moda. A mai volato lei? A me piacerebbe assai tentare un volo!" says Simonetta (112-113). 
In contrast with Futurist notions, which decry nostalgia as "sickly" (Nicholls, 1989:204), is Simonetta's yearning to return to the past, which she remembers with longing: "Tornarvi per rivivere, almeno nei ricordi, il tempo della serena fanciullezza; tornarvi per illudersi di ritrovare sé stessa, come allora" (Messina, 1920b:129). The "sé stessa" of Simonetta's past is the girl who had the freedom to develop her mind. It is significant that her most decisive act is to leave Marcello and return home - to the locus of her intellectual freedom.

In La casa nel vicolo, the oppressive social order intensifies. The protagonists, Nicolina and Antonietta, represent traditional women caught in the web of patriarchy. Centred on the sisters' relationship with don Lucio, Antonietta's husband, the novel places great emphasis on the bond of dominance/subordination between men and women. It focuses on the women's acceptance of Lucio's omnipotence and on his complacency in his authority and "his" women's servitude. Here too, the past is idealised and shown as perfect and happy - because it is the only way out of a present life that is dreary, grim and oppressive, and unlikely to change in the future. Messina uses the present tense to imply a universal truth: "Del resto, è questa la vita di tutte le spose" (Messina, 1992:40). She also applies the narrative technique of free indirect discourse, which creates an equivocal tension within the narrative: there is a "sorta di ambiguità oggettivo-soggettiva in cui è difficile distinguere con sicurezza dove l'autore parli per conto suo o per conto del proprio personaggio" (Cane, 1969:15); and the interplay of irony and resentment that the technique allows suggests the author's intent. Nicolina's contemplations illustrate her mindset: she believes, for example, that don Lucio "sapeva quel che si faceva; era sicuro di sé e conosceva la vita come uno che legge dentro un libro aperto. Bisognava affidarsi a lui, con animo tranquillo" (Messina, 1992:23). "Nicolina portò la pipa al cognato. Era di nuovo immerso fra le carte, accigliato ma tranquillo. [...] E il suo cuore tornò a gonfiarsi della 
sconfinata ammirazione per il cognate" (57). Lucio's omnipotence is seen in the power he holds over his family even in his absence. When Alessio suggests that they go for a walk one day when Lucio is away, Antonietta is unwilling to risk doing something they would never be allowed to do when he is there: "Non so... Papà non c'è... Pare che vogliamo approfittare della sua assenza... / - 'Per fare una innocente passeggiata? concluse Alessio. - Via, mamma, non esageri così! Si decida, almeno per le bambine che non vedono mai un po' di sole!" (100).

The torch of rebellion against patriarchal authority is carried by Alessio. While he is male and not subject to the same restrictions as are women, he is a child and therefore falls into the grouping of "women and children" which is considered both weak and minor ${ }^{1}$. He constantly meets with the disapproval of his father - significantly, for his great love of literature. Don Lucio's reaction to his son's interest is brutal: "Togli via questa roba! - comandò avvicinandosi alla tavola. - Ti ho detto mille volte di non ingombrarmi la casa di cartacce" (112-3). In Alessio, again we have a male protagonist who expresses the author's love of literature. Alessio, however, is more vocal than Marcello, who represents only one who has the freedom to write. Alessio is a stage further in Messina's development of an oppressed being who attempts to break free of his bonds and give voice to his spirit. He repeatedly expresses his frustration and desire to be free. There is a noteworthy passage in La casa nel vicolo, when Alessio, in his penultimate act of rebellion against his oppressive father, clandestinely and disobediently hires a bicycle and pedals it furiously along the seafront. This passage is reminiscent of a passage from

In Messina's era, women had no more legal rights than children. They had no rights over their own property if married - "A wife was not permitted to administer her own property, or even have a bank account without her husband's permission, while the man could dispose at will of his wife's income and property. [...] In some areas (Lombardy and some parts of the Veneto, for example), women's position was actually worsened by the new Code [of 1865] as political rights and private authority were removed from them" (Wood, 1995: 6-7). 
Marinetti's novel, Mafarka il Futurista, in several ways. Marinetti's novel is a fantasy describing the birth of a son who is a "wondrous figlio meccanico, a mechanical child created without woman" (Re, 1989:255), a winged being which Parati (1994:43) describes as a "Futurist Son: the airplane". In Messina's passage, Alessio pedals away on his bicycle, dreaming of taking to the air in a Futurist expression of man become machine, become airplane: "Piegato sulla macchina aveva l'illusione di volare. Fuso in un pezzo solo con la macchina, ali e non pedali egli possedeva!" (1992:115). The passage brings to mind Marinetti's description of Mafarka's son, Gazurmah, who flies "rapidissimo sul mare bianco, oleoso e calmo" (Marinetti, 1973:319): Messina's passage cites the "riva tranquilla" (1992:115) alongside which Alessio rides "sfrenatamente", dreaming of flying. A few other elements are common to both texts: Marinetti mentions the "Sole fuggiasco" (1973:319), while Messina describes the "forte sole vivificatore" (1992:115). Gazurmah is followed through the heavens by a "stormo di condor", "ammansato" by the music made by his wings (Marinetti, 1973:320); while Alessio sees the following scene: "Dall'orizzonte si staccavano nubi piene di rosea luce. Uno stormo di candidi gabbiani volava sul mare" (Messina, 1992:115); both passages are highly poetic. Gazurmah has "polmoni immensi" (Marinetti, 1973:320), while Alessio finds that "si respirava con gioiosa libertà, a pieni polmoni" (Messina, 1992:115). Alessio is racing away from his past, into freedom, away from his mother, aunt and sisters at home: "le donne, le sorelle nemiche" (115). Gazurmah in Marinetti's text has just brutally exterminated Colubbi, his father's concubine, who was calling to him as if she were his mother - "O figlio mio!" (Marinetti, 1973:316). Gazurmah is free and omnipotent, soaring over the chaos and creating music as he goes. Alessio feels, as he rides along, that "anche la mente sembrava aprirsi a più larghi e più audaci pensieri... E un giorno sarebbe fuggito così, fuggito per sempre, senza voltarsi, abbandondo ogni 
cosa, rinnovandosi tutto, come una pianta che si rinnova a primavera" (Messina, 1992:115). He sees himself, like the winged Gazurmah, becoming "una di quelle favolose creature della mitologia - uomini alati" (115). In the oppressive, claustrophobic atmosphere that characterises $L a$ casa nel vicolo, this imagery of flight is the most compelling symbol of the desire for freedom and progress. Alessio's feelings of hatred towards his womenfolk are strongly evocative of the Futuristic view of women as loathsome objects to leave behind: they are part of the restrictive life he would like to abandon and flee.

Although Alessio derides women's weakness, it is significant that he points to their situation: he criticises women for not protesting their plight and aggravating it by passively accepting their subordination. His insight is lucid, where he rails against his imposed confinement and the ban on going to see Manon at the theatre:

"È perfettamente inutile - esclamò Alessio.

- Chi sa ... a coglierlo in un momento buono.

- È inutile - ripeté il fanciullo con amarezza [...].

- E forse è meglio così - fece Nicolina rasserenata.

- Non è meglio - replicò Alessio di nuovo eccitato. - Almeno per me non è meglio. Io non posso fare la vita che fai tu, che fa la mamma o Carmelina... Siete tutte donne. Un lavoruccio fra le mani, o sentir la messa la domenica, basta a svagarvi. Io penso a tante cose... Desidero tante cose... Certe volte mi gira la testa, così forte mi entusiasmo... No, è inutile. Tu non capirai mai!

- Non bisogna lagnarsi... specialmente del padre che ci ha dato la vita!

- Che c'entra! Io non mi lagno. Chi ha parlato di lui, adesso? Gli manco forse di rispetto? Che c'entra lui? È forse colpa mia se non mi contento? Ma tu non puoi capirmi. Tu e 
la mamma vi siete adattate, ora, come la lumaca che ha la forma del suo guscio..." (Messina, 1992:73)

When Alessio expresses his contempt for women's silent acceptance of their condition, he is the first character of Messina's to do so, and it is notable that he speaks as one of the subordinate group, under the authority of his father. If a patriarchal society is one with an unequal distribution of power, in which men have arrogated to themselves all spiritual and temporal power and to women have assigned positions of submission and only symbolic attributes of influence ${ }^{2}$, don Lucio is the one preserving the order. Under the pretext of providing assistance, he accumulates a vast net of people in his debt, enslaved to him forever. But the "assistance" he offers is nothing but usury - and his magnanimity in allowing Nicolina to stay in his house is understood by his complacency in having an unpaid servant who serves the dual purpose of providing conjugal duties when his wife is laid up having babies (69). The illusion he creates of himself is clear in Nicolina's comment: "Non bisogna lagnarsi ... specialmente del padre che ci ha dato la vita!" (73). Part of the illusion created by patriarchal authority is that women are not competent to make a living for themselves, censuring women's work in case they prove their competence and challenge men for their jobs.

Alessio's ultimate stand against this patriarchal repression is a shocking one, constituted by self-obliteration as the only way out of an intolerable situation. His suicide represents an extreme act condemning an

2 Virginia Woolf said that while women in literature were symbolically important, materially they were impoverished: "In the imagination she is of the highest importance; in practice she is completely insignificant. She pervades poetry from cover to cover: she is almost absent from history. She dominates the lives of kings and conquerors in fiction; in fact she was the slave of any boy whose parents forced a ring upon her finger. Woman in literature is only a 'sign'; in truth, recognition in real terms is denied her" (Eagleton, 1986:45). 
oppressive society, embodied by his father. It is interesting how his behaviour is dismissed by don Lucio, patriarchy's mouthpiece, which judges anti-conventionality and anti-conformism by denoting it as sick or mad: "Se è malato si curi. Se è pazzo vada a chiudersi in un manicomio" (94). As a parallel development, his mother Antonietta goes insane, which is the only way she can escape from her unbearable life. In this novel we see Alessio performing two different roles which symbolise the desire and struggle for freedom and progress: he is the mouthpiece against patriarchal, repressive society; and he is also the new Futurist son, fleeing tradition, the past and the female world that colludes with patriarchism to keep him (and those same women) entrapped.

Un fiore che non fiorì (1923) is situated in Florence, in a milieu of fashionable "salons". The novel explores the dichotomy modernity/ traditionalism, focusing on women's increasing emancipation and careers, and on the image of the traditional woman. The plot centres on Franca and her pursuit of the Sicilian Stefano. The principal difference between this novel and its forerunners is that the protagonists are young female "moderns", who as Maria Di Giovanna observes, define their modernity by their haircuts and clothes and their seemingly independent way of thinking - by their "anticonvenzionalità" in their "rapporti amorosi". This anti-conventionality, however, is "più apparente che reale" (1985:75). The novel highlights not the emancipation achieved (or lost) by women in this period (the mid-1920s, as denoted by allusions to Fascism in the text), but rather the great divide encountered when progress meets tradition. Notable in the novel is that the most intrepid of aspiring emancipated women backtrack rapidly when encountering either marriageable men or social censure. Accordingly, to win Stefano's heart, Franca undertakes "un logoramento della propria identità, da riconoscere come unicamente praticabile il modello femminile tradizionale" (Di Giovanna, 1985:77). In Un fiore che non fiori this emancipation is limited to the outer trappings 
of the female self - clothing, hair, and apparent levity in love affairs. As Di Giovanna notes, Franca and her friend Fanny eventually submit completely to society's demands. Fanny, who initiated Franca into the new, daring mode of hairstyle and dress ${ }^{3}$, marries an older man in an attempt to salvage her tatty reputation: "Pure dovrò contentarmi di questa buona occasione! Perché, vedi, in città sono convinti che io ne abbia fatto di tutti i colori" (Messina 1923:73); while Franca is summarily rejected by her beloved's family, despite her efforts to conform. Her past (a year-long correspondence with a beau, several years earlier) has caught up with her and tainted her for life. All she can do is withdraw from public life and bury herself (literally) in the country.

The theme of work as a stimulating occupation for women is expanded in this novel. Education is fundamental to work that provides selfrealisation, and there are numerous references to the studies that Franca's friends are undertaking: Luisa has obtained a degree in Rome; Celeste wants to study medicine; Liliana is interested in art. Franca herself discovers the joy of study and of teaching in the latter part of her short life. These activities give her a sense of fulfilment. At the same time, Messina also emphasises the hostile or scornful attitude that prevails towards women's education:

“- Che fa la Celeste?

- Oh! La Celeste! Si prepara per gli esami di licenza liceale.

- La Celeste?

- Sì, come se non avesse gli anni che à! Vuole studiare medicina, a Roma!

- La Celeste?

\footnotetext{
"Fanny si occupò di lei con gran disinteresse; le fece raccogliere i capelli a crocchia, accorciò le vesti con le sue proprie mani, non abituate a tenere forbici e ago; le insegnò perfino a curarsi le unghie, a portare i tacchi alti, a profumarsi...” (Messina 1923:56).
} 
- Una maniera nuova di cercar marito, che ridere!” (150)

But possibly beneath the scorn Franca and Fanny feel some envy for the strength of purpose demonstrated by those who have the courage to carry out their ambitions in defiance of society:

“- $[\ldots]$ è tornata Luisa da Roma.

- L'ài veduta?

- Sì, l'ò incontrata. À un visino sfiorito.

- Si è laureata?

- Una bella laurea, dicono. Si prepara per un concorso. Pensare che pareva una bambinuccia da non darle due soldi!

- E nessuno di noi si occupava di lei, rammenti? Delle signorine ... E Luisa, con le sue dita sporche d'inchiostro e i tacchi bassi...

- ... ora lei va avanti, e noi restiamo ferme allo stesso posto. Che abbiamo fatto in tanti anni?

- Davvero! Che abbiamo fatto? Ma i libri l'ànno imbruttita!" (63-4) (Italics mine)

The envy felt by Fanny, now a domestic archetype, is later felt more sharply by Franca, who having withdrawn to the countryside discovers the world available to her through the written word: "Sfogliando qua e là $i$ libri abbandonati si mortificò accorgendosi di essere molto ignorante; ed ebbe curiosità d'imparare" (171). Franca discovers her sense of self only once she removes herself from society: alone, she is free to explore her intellect without fear of scorn or, significantly, without the obstacle presented by her father - enforcer of the patriarchal code which suppresses women by keeping them uneducated and dependent: "Provvederò io all'avvenire di Franca. Intanto è inutile che vada a scuola. Falle studiare in casa ciò che le piace: 1'unica figlia del cavaliere Gaudelli 
non à bisogno di guadagnarsi un pane" (57). The question of "need" to earn one's bread has been expediently transformed into a case of social status, dismissing any case of "want" to earn it. Liliana is described as having acquired a diploma enabling her to teach, as have her six sisters. Yet these diplomas are left unused while their father is able to maintain them: the diplomas will serve in case of emergency, if they do not find husbands.

Stefano Mentesana does not represent a channel for Messina's ideas on female liberation. He is neither literary nor sensitive and has no yearnings for freedom: he is a free man, a traditional man, and he wants a woman cast in the image of the Virgin Mary. While carnally desiring painted ladies on the streets of Florence, and attracted to Franca because she resembles a mysterious Valeria from his past "che lui avrebbe adorato in ginocchio" (12), he rejects Franca because of her previous acquaintances - whom she has never so much as chastely kissed ${ }^{4}$. Messina here has portrayed a clear image of the patriarchal male who upholds and reinforces the moral/sexual double standard. Stefano represents the man from whom emancipated women should move away, and his rigid hypocritical principles are displayed as a signpost of caution to women.

The characters in this novel exert no strong pressure for change and achieve none. Rather, they revert to the safety of tradition or obliterate themselves in the face of social censure and alienation. Messina's sharply defined portrayal of this society permits insight into its hypocrisies, its profoundly rooted conventions and the difficulty of challenging its fundamental structure.

4 "Come dire, come dire a Cesare che un bacio non l'à mai sfiorata? Che ella è pura, come Maria Luisa?" (123-4). Maria Luisa is Stefano's virginal sister, considered by him to be the ideal woman. 
In the last two novels, Le pause della vita (1926) and L'amore negato (1928), a substantial advancement in female emancipation may be seen. In the protagonists of the novels, Paola and Severa, we see a level of determination and self-assertion which defines them as strong, autonomous individuals. In Le pause della vita progress and liberation are no longer associated with a peripheral character or a male, but with Paola herself. She pursues a literary dream, and is working on a translation of an English novel, seeking mental stimulation and meaning in her life: "Non aveva forse voluto lavorare per non dipendere, per dare uno scopo alla sua umile vita?" (Messina 1926:196). No longer content to accept docilely the roles assigned to her by society - where marriage is the primary occupation, and teaching one of few professional options available Paola is evolved enough to reject the concept of teaching, recognising it as an unsatisfactory means of finding the stimulation she needs: "Perché era tornata a scuola? Per pigliare una patente e fare la maestra? invecchiare insegnando le stesse cose a una minuscola turbolenta scolaresca che cambia ogni anno?" (66). She wants to write as a career: "Dopo la traduzione avrebbe scritto una storia più interessante della storia di Miss Sally. E il suo nome sarebbe andato lontano" (134). She is courageous enough to see her dream through: her translation is published, sells "a vele gonfie" (192), and she is commissioned to translate a second novel. She discovers the pleasure of freedom and self-determination: "la speranza di bastare a sé stessa, di farsi un nome, metteva una specie di nobiltà e di bellezza nella sua nuova esistenza" (193). Paola's joy in self-improvement does not reflect improving circumstances for women. Le pause della vita was published in 1926 - the year Fascist law barred women "dai concorsi a cattedra per l'insegnamento di lettere, storia, filosofia nei licei classici e scientifici, e dalle cattedre d'italiano e storia negli istituti tecnici" (Turnaturi, 1993:103), and these restrictions are described in the novel - 
the female workers in the post office where Paola works are forced out by war veterans:

Parlando tutte e due in una volta, interrompendosi, sospirando, le colleghe raccontarono a Paola che alcuni 'ex combattenti' erano entrati in ufficio, mettendosi al posto delle impiegate. - Il giornale dice: 'ànno invaso l'ufficio' corresse la Parigi -. È la parola giusta.

- Fuori le donne! Fuori le donne! - ripeté la Boncini.

- Noi raccogliamo prepotenze e ingratitudini, dopo aver fatto camminare la posta come un orologio. Ma io lavoro qui da sei anni. (Messina 1926:94-5)

In Le pause della vita different characters are associated with past and future, which are further linked to the dichotomy of country/city, and in this novel, Futurist (and Fascist) dichotomies of past and future are very evident. While Futurism and Fascism shared many ideals (war, violence, man the soldier, patriotism ${ }^{5}$ ), Futurism diverges from Fascism in its connotations of past and future, country and city, and the way they both relate these to the figure of woman. Lucia Re's discussion of Fascist theories of women identifies an interesting perspective of Fascism's view of modernity: Fascism sees itself as emblematic of what is "modern" and sees the "death of feminism and of the equal rights movement [as] a fundamental achievement of modernity because it has restored the sharply defined difference between man and woman" (Re, 1995:82). Whereas

5 "Futurism and Fascism appear intimately linked in their bombastic, militaristic style, their use of propaganda and their linking of politics and aesthetics, as well as their overall worldviews" (Orban, 1995:72). 
Futurism extolled the city and saw it as the future ${ }^{6}$, the Fascist party line discouraged the glorification of the city, and encouraged the return to traditional farming communities: "Un altro falso miraggio di felicità è offerto dall'aspetto illusorio delle grandi città che attirano facilmente le sane e robuste forze della campagna stornandole così dalla produzione di una ricchezza fondamentale per l'economia di una nazione" (Ardali, 1924:23-5). Fascism disapproved of the woman being in the city: "La donna che - senza la più assoluta e comprovata necessità - lascia le pareti domestiche per recarsi al lavoro, la donna che, in promiscuità con l'uomo, gira per le strade, sui trams, sugli autobus, vive nelle officine e negli uffici, deve diventare oggetto di riprovazione" (Loffredo, 1938:365). As Wood points out, "The dominant female image of Fascist rhetoric was rural rather than urban" (1995:97) whereas Futurism sees "la terra", the land, in its association with the essence of womanhood (105) in a negative way. Lucia Re further observes that "nature is the most passatista of all of futurism's enemies" (1989:255). Marinetti wrote in 1915 that the woman was "divenuta il simbolo della terra che si deve abbandonare" (1990:297). We may see the two women in this novel as representing the two movements: Signora Tina, Paola's mother, that of Fascism; Paola that of Futurism. Signora Tina associates the past with all that is good and rigidly holds on to tradition and convention. She is a woman of the earth, tied to the traditions of the past. For Paola, the Past represents a "mondo antico, chiuso" and the Future liberation and light - Futurist ideals: "Il tempo apriva il pugno chiuso, per mostrarle i doni tenuti in serbo. Il passato era sparito. Ella era libera e pura" (Messina, 1926:193). Signora Tina is

6 "[I]nnalziamo fino al cielo l'imponente geometria dei ponti metallici e degli opifici chiomati di fumo, per abolire le curve cascanti delle vecchie architetture" (Marinetti, 1973:27). The Futurist architect Sant'Elia wrote "Noi dobbiamo inventare e rifabbricare la città futurista simile ad un immenso cantiere tumultuante, agile, mobile, dinamico in ogni sua parte, e la casa futurista simile ad una macchina gigantesca" (Marinetti, 1973:150). 
associated with the countryside and never wants to leave it: "la vita di sua madre era lassù, tra i campi di San Gersolé, ricchi di luce di verde e di pace, che solo la terra non tradisce mai" (177). She has a negative impression of electric light, a feature of the city. Paola dreams of the city and goes to it as soon as she can. The countryside has connotations of darkness for her while she envisages the city as filled with electric light, another concept glorified by Futurism? " "In città doveva essere già buio; nelle strade dovevano essere accese le grandi lampade elettriche. Pensò all'interno delle stanze intravedute, ora illuminate" (22).

Paola cannot sustain her success and independence: society and convention rear up against her in the form of her past (an out-of-wedlock pregnancy). She withdraws to a nunnery, as an alternative to killing herself. Despite her "modernness", she cannot reconcile her past impurity with an offer of marriage made to her in the belief that she is pure. But Paola's self-abnegation comes from more than a strong moral sense: she is fiercely opposed to the notion of marriage, which despite her love for her childhood boyfriend Matteo, she resists from beginning to end: "Era il momento di dire: - Non domani. Mai più. Noi dobbiamo essere liberi" (18); "Abiterò una bella casa, tutta mia - si ripeteva con gioia - e vivrò sola sola perchè nessuno mi comandi di andare dove non mi piace" (54).

It is difficult to understand how one who loves freedom as much as Paola does could condemn herself to seclusion rather than opting to remain alone. But perhaps this difficulty comes from our perspective almost a century later, when many women have freedom of choice. Very likely, this ending is indicative of Messina's inability to take her heroine all the way; her daring does not carry her so far as to flout convention and

\footnotetext{
7 "Ed è l'elettricità che ne cura precipitosamente il germogliare. Tutta l'elettricità atmosferica immanente sopra di noi, tutta l'incalcolabile elettricità tellurica sono finalmente utilizzate" (Marinetti, 1990:320).
} 
she retreats into the shelter of morality. We also cannot forget that the Fascist regime extended its power to the censorship of all printed material: a novel promoting women's emancipation, extramarital pregnancy and the refusal of marriage would not have been allowed to be published. Giovanni Ragone observed that "Se si considera l'arco del ventennio nero, risulta evidente un vistoso e progressivo scivolare verso il controllo di Stato, sempre più esteso e repressivo, sull'editoria" (Ragone, 1989:10531054). By 1932, Ragone said, publishing houses were lined up either against (few) or with Fascist ideology. Bemporad, who published some of Messina's children's books, was decidedly pro-Fascist; Sandron and Vallardi toed the party line, and Treves - the publishers of Le pause della vita - "sotto l'influenza di Gentile [...] si trascinava sui vecchi titoli del suo catalogo" (1061). Hence, Paola's renunciation and refusal to marry is justified as "Nessuno è libero di sé stesso: nel farci male noi dobbiamo inevitabilmente ferire qualche altro che è legato a noi da fili invisibili e tenaci" (213). Messina shows that in this world, the power of society is stronger than the individual, and it is almost impossible to challenge its iron-cast edifices.

Messina's last novel, L'amore negato (1928) traces the rise and fall of Severa, determined to become financially autonomous and famous. Severa's personality is not a congenial one, and as she makes her way through life exploiting her benefactors, maltreating her family and alienating her clients, it appears as though the purpose of the novel is the disparagement of ambition. Severa does not inspire the sympathy of the reader, and the narrative voice reinforces this, describing her unscrupulous actions (her courting of the dying old landlady in order to inherit her house, the banishment of her family to the dank, dark basement, her untrammeled ambition and ignorance of the social pecking order, which estranges her wealthy clients). Severa's avaricious nature is clearly 
described when the old lady indicates she will bequeath Serena her possessions:

- Sei un angelo, cara! Ma tu non ti sarai sacrificata inutilmente! L'ansia tornò a luccicare negli occhi di Severa che si alzò, eccitata, con una scusa, e si rimise a sedere intrecciando le mani fino a farsi male, per calmarsi. (Messina 1993:26)

- Lascia che domani, mentre ancora posso farlo, scriva con la mia mano.

- Che cosa, zia?

- Quanto è nella mia volontà. La gente è cattiva. La roba può andare dispersa, dopo la mia morte. Tu sai che non voglio beneficare i miei parenti, che non se lo meritano.

Severa non rispose. Nella penombra della stanza, i suoi occhi lucevano come occhi di gatto. Intrecciava le mani, sino a farsi male per non parlare. (29)

The end of the novel sees Severa alone, a failure, considered mad by the neighbourhood (the children "avevano una certa paura di lei; le loro madri, se facevano le bizze, li minacciavano di chiamare 'la Matta' che abitava a Santa Maria") (120) and rejected by the young man with whom she has fallen in love. The flyleaf of the Sellerio edition of L'amore negato describes the novel as "il più pessimista" in which one sees punished "la ribellione al destino". While it is true that the novel offers no glimmer of hope, it raises interesting questions. It is the novel in which Messina fully explores the concept of ambition in a female protagonist, and if Severa fails in the end, it is due to her personality, which is hard and unscrupulous. The character of Severa is revolutionary, as she represents a complete departure from Messina's earlier traditional figures 
of woman. She has rejected the traditional characteristics of womanhood, excluding marriage from her plans, scorning it - "Un matrimonio? - fece la signora Emilia. - Guai a parlare di matrimonio, di amore, di innamoramenti! Non è una ragazza comune!" (35), and from childhood she has been uncommonly independent - "Sempre le era piaciuto "sapere andare per conto suo', fin da piccolo" (124).

She is Messina's first female protagonist to recognise and vehemently to decry the destiny of women to be victims: "Io la piegherò, questa sorte! Non mi lascerò sopraffare come te, come nostra madre, come tante che conosco e che non mi fanno pietà, anzi mi indignano, perché ciascuno di noi ha il destino che si merita" (22-3). She has set herself a goal to achieve: "Sentiva di dovere raggiungere una mèta posta al di là del segno che pareva assai lontano negli umili giorni della sua umile vita di ragazza dall'oscuro avvenire. Quale mèta? Nessuno prevede dove sarà portato dalla sua forza e dalla sua ambizione" (71). She has realised that to succeed, she must be hard, decisive and resolute: "Severa girava da per tutto, sorvegliava, dava ordini, facendosi obbedire come fosse nata per comandare" (57). About men, she nourishes no romantic illusions - when her mother asks Severa to assist her sister Miriam with a dowry, Severa answers cynically, "Miriam non sarebbe felice col suo Gaddi! Egli la tradirebbe dopo due giorni" (67).

Whereas Messina's previous women have passively endured their condition, constrained by convention and law which impose different sets of rules for male and female behaviour, Severa is the only one to rebel against female destiny and to carve out her own fate. The reason she fails - not to achieve her dream, for she does achieve it, but to maintain it - is because she cannot see the limits of her strength, or use it to benefit others. Morally, she does not deserve reward. Like all Messina's women before her, Severa sees society rearing up in its greater strength against her. But it is not through her defiance of convention that her downfall is 
incurred. Severa's decline results from the commission of two capital sins: Pride and Avarice. Her undoing is directly traceable to her uninvited participation in an exhibition, intended for social circles in which she has no place:

Oh, una piccola innocua vendetta ben meritata dalle sue clienti, che ricorrevano a lei anche in questa occasione, umiliandosi a confessare le loro gelosie piccine, la loro smania di primeggiare e poi, se l'incontravano nel Corso, la salutavano freddamente: per farle misurare la gran distanza che la separava da loro [...]. (63-4)

Messina portrays Severa as an individual who has gone too far in her ambition, allowing it to overstep and overwhelm her humanity; she also portrays her as a woman who has tried too hard not to be female. We need to ask why Messina has chosen as her strongest heroine, one who has such negative qualities - she is ruthless, unscrupulous, unkind and unbending. A possible answer to this may be that Messina perceives all too well that in her lifetime, and in Severa's lifetime, the world of professional success is a man's world, and for a woman to succeed on a par with men she must reject all womanly qualities. Severa has recognised that to be soft, selfsacrificing and generous - feminine, motherly traits - is incompatible with doing business. Alternatively, her failure may also be Messina's attempts to toe the Fascist party line, by not allowing a woman to achieve success in the world of business.

Severa's counterpoise is her sister, Miriam, who represents the ideal woman: her goal is marriage, she aspires to a "normal" domestic life, and she stays at her mother's side as her hopes for marriage recede. Miriam presents the "good" self-sacrificing virtues associated with mothers: "Appagata di vivere la vita degli altri. Sempre convinta di dovere raggiungere uno scopo, di essere necessaria a qualcuno. Se domani la 
madre fosse morta, ella avrebbe trovato da offrire il suo bene a qualche altra creatura" (110). However, Miriam is not rewarded by Messina for her goodness - her dream of marriage goes unfulfilled, and even the patch of ground outside her tiny house remains untended and arid, as if attesting to the sterility of her life: "Solo nel pezzo di terra davanti il portoncino della casa di Miriam non cresceva un fil d'erba" (128). Miriam by the end is bitter, and this is revealed in the proverb she repeats to Severa: "Non lo sai che per raccogliere bisogna prima seminare?" (128). But this is ironic, because Miriam herself has reaped nothing, despite the years she has spent investing her energies in the wellbeing of those around her. Therefore, while Messina appears to have punished Severa by leading her to a lonely, impoverished existence, as Showalter observes of other women novelists of the era with their "assertive heroines" (1977:28), it does not appear that Messina has cast a value judgement on Severa, since Miriam's fate is just as bleak. Instead, Messina seems to cast judgement on those very virtues which society has always held so dear - those "good" womanly virtues praised by society and even rewarded with prizes by the Fascist government (Quartermaine, 1991:235) - implying that they are fruitless and futile; they will not bring one happiness and fulfilment.

Messina has not presented Severa and Miriam's story to prescribe the best and most moral way of living - rather, as does George Eliot in Middlemarch, she "avoids any crude kind of social determinism; her characters are both agents and patients in the human scene, just as we all are" (Harvey, 1985:18). What is said of Eliot's character, Lydgate, and his failure, reflects precisely Severa's situation: "Lydgate fails, not just because of circumstances, but also because of intrinsic flaws, those 'spots of commonness in his nature" (18). As a human being, Severa has great failings, and these are the major reasons for her fall. But why then does Miriam not succeed? The underlying theme of L'amore negato is the struggle of the individual within society, and within the greater sphere of 
things, the cosmos. Messina shows how mankind and womankind are governed by two invincible forces: convention and fate. Severa meets with ostracism because of her unkind nature and her refusal to bow to convention's requirements; Miriam who is good and kind ends up in a life of bleak poverty because of the arbitrary hand of fate.

Messina has gone beyond notions of past and future, tradition and progress, in this novel, as she has shown that nothing correlates, nothing is predictable, and reward is not the logical consequence of goodness. She may have brought her protagonist, Severa, to full evolution as a liberated, autonomous female, but in order to do this, to acquire equality, autonomy and material success she has had to sacrifice her female essence. Severa's failure is an indictment of society which has brought things to this pass. Messina's message is that as things stand, there is no hope for women to achieve emancipation and equality and still find happiness and acceptance in society. The pessimism of the novel could be attributed to the futility of the search for fulfilment: if being unwomanly gets one nowhere, and being "good" and maternal nowhere further, what is the secret to the quest? The novel ends on a question mark and on an exhortation which could speak for the whole of Womankind, torn between alternatives which bring no peace, and awaiting solutions that tarry in coming:

"Signore! Signore! Che ne sarà di lei?"

(University of Cape Town)

\section{References}

Ardali, P.

1924 La politica demografica di Mussolini. Mantova: Casa Ed. "Mussolinia". 
Bimbi, F.

Cane, E.

Chiavola Birnbaum, L.

Di Giovanna, M.

Eagleton, M. (ed.)

Evans, R.

Fogazzaro, A.
1977 Sociologia della famiglia e ideologia del ruolo della donna. In Bimbi, F. (ed) Dentro lo specchio. Milano: Gabriele Mazzotta editore.

1969 Il discorso indiretto libero nella narrativa italiana del Novecento. Roma: Silva Editore.

1986 Liberazione della donna: feminism in Italy. Middletown, Connecticut: Wesleyan University Press.

1985 La fuga impossibile: Sulla narrativa di Maria Messina. Università di Palermo: Federico \& Ardia.

1986 Feminist Literary Theory: A Reader. Oxford: Basil Blackwell.

1977 The Feminists: Women's Emancipation Movements in Europe, America and Australasia 1840-1920, London: Croom Helm; New York: Barnes \& Noble.

1968 Lelia. I Capolavori di Antonio Fogazzaro. A cura di Giorgio De Rienzo. Milano: U. Mursia \& C. 
Forsås-Scott, H.

Gherarducci, I. (ed.)

Griffin Wolff, C.

Harvey, W.J.

Loffredo, F.

Lombroso, G.

Marinetti, F.T.
1991 Textual Liberation: European Feminist Writing in the Twentieth Century. London: Routledge.

1976 Il futurismo italiano. Roma: Editori Riuniti.

1977 A Feast of Words: The Triumph of Edith Wharton, New York, Oxford University Press. Cited by Showalter, E. 1977. A literature of their own. British women novelists from Brontë to Lessing. Princeton, New Jersey: Princeton University Press.

1985 Introduction to Middlemarch. George Eliot. London: Penguin Books.

1938 Politica della famiglia. Milano: Bompiani.

1939 Politica della famiglia e della razza. La difesa della razza (3) 2.

1921 L'anima della donna. Bologna: Zanichelli.

1923 La donna nella vita. Bologna: Zanichelli.

1973 In De Maria, L. (ed) Per conoscere Marinetti e il Futurismo. Milano: Arnoldo Mondadori Editore. 
1990 In De Maria, L. (ed) Teoria e invenzione futurista. Milano: Arnoldo Mondadori Editore.

Messina, M.

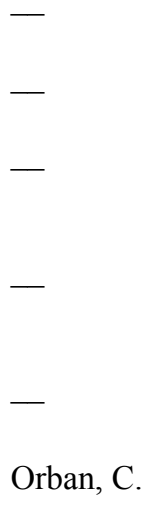

Parati, G.

Quartermaine, L. 1920a Primavera senza sole. Napoli: Gennaro Giannini.

1920b Alla deriva. Milano: Fratelli Treves.

1992 La casa nel vicolo. Palermo: Sellerio.

1923 Un fiore che non fiorì. Milano: Fratelli Treves Editori.

1926 Le pause della vita. Milano: Fratelli Treves Editori.

1993 L'amore negato. Palermo: Sellerio.

1995 Women, Futurism and Fascism. In Pickering-Iazzi, R. (ed) Mothers of Invention: Women, Italian Fascism, and Culture. Minneapolis, London: University of Minnesota Press.

1994 The Transparent Woman: Reading Femininity within a Futurist context. In Miceli Jeffries, G. (ed) Feminine Feminists: Cultural Practices in Italy. Minneapolis: University of Minnesota Press.

1991 "Women's viewpoint: expectations and experience in twentieth-century Italy". In: Forsås-Scott, H. (ed) Textual 
Ragone, G.

Rasy, E.

Re, L.

Showalter, E.

Spinazzola, V.

Turnaturi, G.
Liberation: European Feminist Writing in the 20th Century. London \& New York: Routledge.

1989 "Editoria, letteratura e comunicazione". Letteratura italiana Einaudi, Storia e geografia, L'età contemporanea. Torino: Einaudi.

1984 Le donne e la letteratura. Roma: Editori Riuniti.

1989 Futurism and Feminism. Annali D’Italianistica. Vol. 7. 253-272.

1995 Fascist Theories of "Woman". In Pickering-Iazzi, R. (ed) Mothers of Invention: Women, Italian Fascism, and Culture. Minneapolis, London: University of Minnesota Press.

1977 A literature of their own. British women novelists from Brontë to Lessing. Princeton, New Jersey: Princeton University Press.

1991 Sister's Choice: Traditions and Change in American Women's Writing. Oxford: Clarendon.

1987 Introduzione. In: Deledda, G. La madre. Milano: Mondadori.

1993 Scuola e istruzione. In: Mafai, M. (ed) Ledonne italiane: il chi è del '900. Milano: Rizzoli. 
Wood, S.

1995 Italian Women's Writing 1860-1994.

London \& Atlantic Highlands, NJ: The Athlone Press. 